\title{
Retroperitoneal Giant Mixed Adenoneuroendocrine Carcinoma: Case Report
}

\author{
Selçuk Kaya, Yunus Emre Altuntaş, Önder Altın, Ahmet Feran Ağaçhan, \\ Hasan Fehmi Küçük, Metin Kement, Levent Kaptanoğlu, Nejdet Bildik
}

Department of General Surgery, Kartal Dr. Lütfi Kırdar Training and Research Hospital, İstanbul, Turkey

Submitted: 11.09.2017 Accepted: 02.01.2018

Correspondence: Selçuk Kaya, Kartal Dr. Lütfi Kırdar Eğitim ve Araştırma Hastanesi, Genel Cerrahi Kliniği, İstanbul, Turkey E-mail: selcukkaya_36@hotmail.com

Keywords:
Cystadenocarcinoma; imaging
examinations; mucocele.

\begin{abstract}
Mucinous cystadenocarcinoma remains the second most frequent cause of appendiceal mucocele. Presently described is a case of mixed adenoneuroendocrine carcinoma (MANEC) located in the right retroperitoneal space. A 64-year-old male was admitted with a palpable mass in the right lower quadrant. An abdominal computed tomography scan revealed a cystic mass in the pelvic area $31 \times 25 \times 25 \mathrm{~cm}$ in size. A search of the literature yielded more than 50 similar cases, with mean diameter of 13 to $40 \mathrm{~cm}$; however, only a few of these cases were mucinous cystadenocarcinoma. Usually, an appendectomy is sufficient therapy for cystadenoma and hyperplasia, while a right hemicolectomy is required for cystadenocarcinoma. To our knowledge, the present case is the first with a pathological diagnosis of MANEC (30/70 neuroendocrine carcinoma and adenocarcinoma) to be reported.
\end{abstract}

\section{INTRODUCTION}

Appendiceal mucocele is a rarely seen disease characterized by dilation of the appendiceal lumen with mucus. The accumulation of excessive mucin causes abnormal dilation, leading to the formation of a cystic mass. ${ }^{[1,2]}$ The second most prevalent form of appendiceal mucocele is mucinous cystadenocarcinoma. ${ }^{[3,4]}$ The incidence of adenocarcinoma in the histopathological examination of all appendectomy specimens has been reported to be $0.08 \% .^{[5,6]}$ Approximately $40 \%$ of all appendiceal adenocarcinomas are mucinsecreting mucinous adenocarcinoma. ${ }^{[7]}$ Mucoceles may rupture spontaneously or during surgery and develop into pseudomyxoma peritonei. ${ }^{[8]}$ This case report describes a giant (maximal diameter: $31 \mathrm{~cm}$ ), rarely seen, appendiceal mixed adenoneuroendocrine carcinoma (MANEC) filling the right retroperitoneal cavity of a 64-year-old male patient.

\section{CASE REPORT}

A 64-year-old male patient had complaints of difficulty walking persisting for a year, but which had become aggravated in the previous 3 months, swelling of the right foot, pain in the right lower quadrant, weight loss, and pretibial edema. A physical examination revealed abdominal distension and a palpable mass in the right lower quadrant His laboratory findings were within normal limits. Abdominal computed tomography $(\mathrm{CT})$ revealed a multiseptated cystic mass $(31 \times 25 \times 25 \mathrm{~cm})$ with patchy areas of calcification that filled the right abdominal quadrant and extended from the lower edge of the liver to the pelvis and obscured the planes around the iliopsoas muscle. The mass was adjacent to the right kidney, right iliac artery, and the ureter (Fig. I). Intraoperatively, a mass lesion extending from the liver to the pelvis and approaching the midline was observed. A giant mucocele was separated from the 


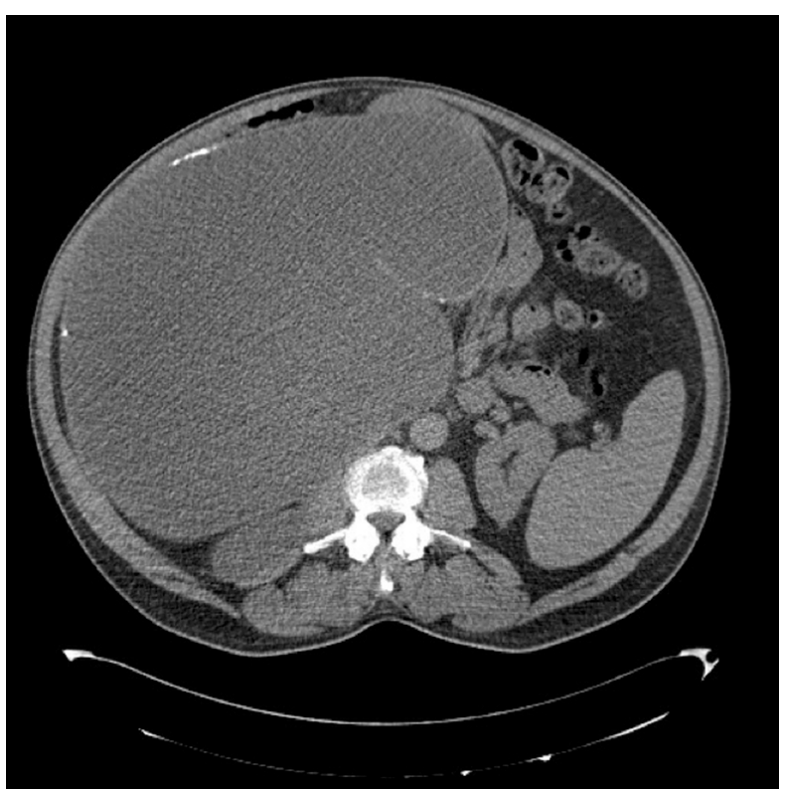

Figure 1. A multiseptated cytic mass measuring $31 \times 25 \times 25 \mathrm{~cm}$ that largely filled the right side of the upper abdominal cavity and extended from the subhepatic space to the right pelvis.

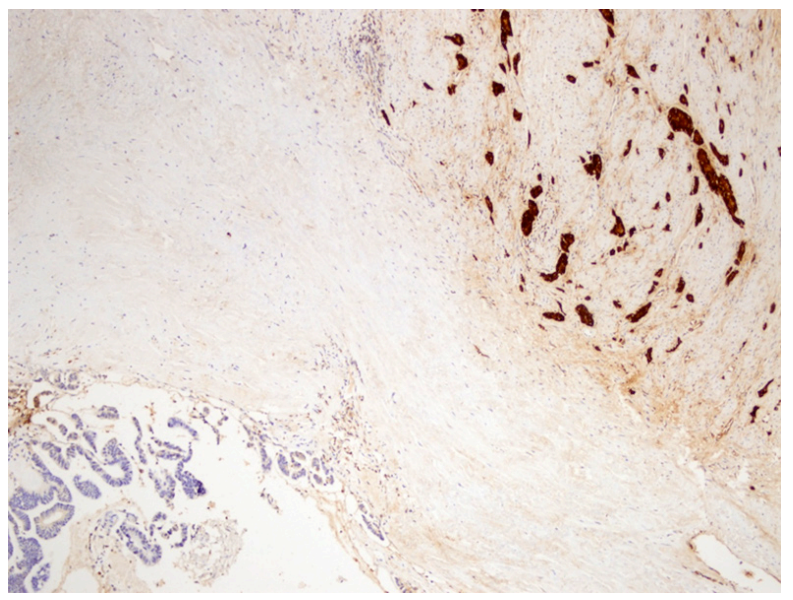

Figure 2. Diffuse pools of mucin consistent with mixed appendiceal adenoneuroendocrine carcinoma and the focal atypical glandular structures of neuroendocrine carcinoma/adenocarcinoma with a ratio of $30 / 70$.

adjacent organs and tissues with sharp dissection, and a tumoral mass originating in the retrocecal appendix was detected. The mass was removed en bloc with a right hemicolectomy. Histopathological examination of a sample revealed appendiceal MANEC (30/70 neuroendocrine carcinoma/adenocarcinoma) (Fig. 2). The diagnosis of this case was consistent with the 2010 World Health Organization classification of MANEC. ${ }^{[9]}$ The patient underwent a regimen of oxaliplatin, folinic acid and infusional 5-fluorouracil (FOLFOX-4) as postoperative adjuvant chemotherapy. No local recurrence was detected in 2 years of follow-up.

\section{DISCUSSION}

Appendiceal mucocele is rare. It is a cystic mass that emerges following neoplastic changes to the appendiceal mucosa; the lumen becomes enlarged due to an abnormal accumulation of mucus. ${ }^{[1,2]}$ Mucocele of the appendix was first defined by Rokitansky. ${ }^{[4]}$ There are 4 histological types: simple mucocele or retention cyst, mucosal hyperplasia, mucinous cystadenoma, and mucinous cystadenocarcinoma. ${ }^{[10,11]}$ Mucinous cystadenocarcinoma is the most frequently seen type after mucinous cystadenoma, and constitutes $11 \%$ to $20 \%$ of appendiceal mucoceles. A review of the literature revealed some 50 cases of large mucoceles, with a mean diameter of between 13 and 40 $\mathrm{cm}$. However only a very few of these were mucinous cystadenocarcinoma. ${ }^{[12,13]}$ Cases of MANEC are very rare.

Abdominal CT aids in the differentiation between appendiceal mucocele and other lesions that may mimic appendiceal mucocele. The presence of a nodule on the wall of the mucocele may be considered suggestive of mucinous cystadenocarcinoma. ${ }^{[l]}$ In our case, in images, the wall of the cystic lesion in the right lower quadrant resembled the intestinal wall. The lesion extended to the cecum, and at the junction with the cecum, concentric layers typical of mucocele were detected. All of these radiological findings established the diagnosis of appendiceal mucocele. However, it is very difficult to differentiate between cystadenoma and cystadenocarcinoma preoperatively. ${ }^{[7,14]}$ Tumor markers, such as carcinoembryonic antigen and cancer antigen 19.9, are not very valuable in this instance. ${ }^{[15,16]}$

Surgical strategies for these patients differ widely. As a standard approach, although an appendectomy is considered sufficient in cases of cystadenoma or hyperplasia, in patients with cystadenocarcinoma it should be combined with a right hemicolectomy. ${ }^{[17,18]}$ If there is no involvement of a neighboring mesenteric organ or peritoneal involvement, then removal of the appendix with its mesentery will suffice in cases of cystadenocarcinoma. ${ }^{\left[{ }^{[9]}\right.}$ However, if there is invasion of the surrounding organs or tissues, then a right hemicolectomy is advised. Although there is controversy about a preference between open and laparoscopic surgery in cases of appendiceal mucocele, open surgery is recommended in cases with cystadenocarcinoma due to the large size of the lesion and the risk of rupture. In our case, we performed a right hemicolectomy using an open approach.

In conclusion, these rare cases can grow to tremendous size and push away the adjacent organs. Preoperative evaluation and determination of the appropriate surgery strategy is very valuable.

Informed Consent

Approval was obtained from the patients. 


\section{Peer-review}

Internally peer-reviewed.

\section{Authorship Contributions}

Concept: S.K., Y.E.A., Ö.A.; Design: S.K, Y.E.A.; Data collection \&/or processing: S.K, Y.E.A., Ö.A.; Analysis and/or interpretation: S.K., Y.E.A., Ö.A.; Literature search: S.K., Y.E.A.; Writing: S.K., Y.E.A., Ö.A.; Critical review: S.K., Y.E.A., Ö.A.

\section{Conflict of Interest}

None declared.

\section{REFERENCES}

1. Madwed D, Mindelzun R, Jeffrey RB Jr. Mucocele of the appendix: imaging findings. AJR Am J Roentgenol 1992;159:69-72. [CrossRef]

2. Aho AJ, Heinonen R, Laurén P. Benign and malignant mucocele of the appendix. Histological types and prognosis. Acta Chir Scand 1973;139:392-400.

3. Higa E, Rosai J, Pizzimbono CA, Wise L. Mucosal hyperplasia, mucinous cystadenoma, and mucinous cystadenocarcinoma of the appendix. A re-evaluation of appendiceal "mucocele". Cancer 1973;32:1525-41. [CrossRef]

4. Aranha GV, Reyes CV. Primary epithelial tumors of the appendix and a reappraisal of the appendiceal "mucocele". Dis Colon Rectum 1979;22:472-6. [CrossRef]

5. Alican F. Apendisin başka hastalıkları. In: Alican F, editor. Genel Cerrahi Cilt I. İstanbul: Nobel Tip Kitabevi; 2007. p. 445-48.

6. Rassu PC, Cassinelli G, Ronzitti F, Bronzino P, Stanizzi T, Casaccia M. Primary adenocarcinoma of the appendix. Case report and review of the literature. Minerva Chir 2002;57:695-8.

7. Lo NS, Sarr MG. Mucinous cystadenocarcinoma of the appendix. The controversy persists: a review. Hepatogastroenterology 2003;50:432-7.
8. Dachman AH, Lichtenstein JE, Friedman AC. Mucocele of the appendix and pseudomyxoma peritonei. AJR Am J Roentgenol 1985;144:923-9. [CrossRef]

9. Bosman FT, Carneiro F, Hurban RH, Theise ND. WHO Classification of Tumours of the Digestive System. 4th ed. Lyon: IARC; 2010.

10. Soweid AM, Clarkston WK, Andrus CH, Janney CG. Diagnosis and management of appendiceal mucoceles. Dig Dis 1998;16:183-6.

11. Dixit A, Robertson JH, Mudan SS, Akle C. Appendiceal mucocoeles and pseudomyxoma peritonei. World J Gastroenterol 2007;13:23814. [CrossRef]

12. Arly KS, Stephenson DV Jr, Davis WC. Giant retroperitoneal mucocele simulating pseudomyxoma peritonei and mucinous adenocarcinoma. Am J Surg 1968;116:439-43. [CrossRef]

13. Snyder TE, Vandivort MR. Mucinous cystadenocarcinoma of the appendix with pseudomyxoma peritonei presenting as total uterine prolapse. A case report. J Reprod Med 1992;37:103-6.

14. Rutledge RH, Alexander JW. Primary appendiceal malignancies: rare but important. Surgery 1992;111:244-50.

15. McFarlane ME, Plummer JM, Bonadie K. Mucinous cystadenoma of the appendix presenting with an elevated carcinoembryonic antigen (CEA): Report of two cases and review of the literature. Int J Surg Case Rep 2013;4:886-8. [CrossRef]

16. Lakatos PL, Gyori G, Halasz J, Fuszek P, Papp J, Jaray B, et al. Mucocele of the appendix: an unusual cause of lower abdominal pain in a patient with ulcerative colitis. A case report and review of literature. World J Gastroenterol 2005;11:457-9. [CrossRef]

17. De Abreu Filho JG, De Lira EF. Mucocele of the appendix: appendectomy or colectomy? J Coloproctol 2011;31:276-84. [CrossRef]

18. Nitecki SS, Wolff BG, Schlinkert R, Sarr MG. The natural history of surgically treated primary adenocarcinoma of the appendix. Ann Surg 1994;219:51-7. [CrossRef]

19. Turaga KK, Pappas S, Gamblin TC. Right hemicolectomy for mucinous adenocarcinoma of the appendix: just right or too much? Ann Surg Oncol 2013;20:1063-7. [CrossRef]

\section{Retroperitoneal Dev Mikst Adenöroendokrin Karsinom: Olgu Sunumu}

Apendiks mukoselinin en yaygın ikinci görülme şekli musinöz kistadenokarsinomdur. Sağ retroperitoneal boşluğun tamamına yakını dolduran nadir görülen miks adenöroendokrin karsinom (MANEC) olgusu sunulmaktadır. Altmış dört yaşında erkek hasta; sağ alt kadranda palpabl kitlesi mevcuttu. Bilgisarlı batın tomografisinde (BBT) $31 \times 25 \times 25 \mathrm{~cm}$ boyutlarına ulaşan multisepatalı kistik kitle görülmüştür. Literatürde 50 olgu rapor edilmiş olup; büyük ve dev mukosellerin ortalama çapları I 3 ile $40 \mathrm{~cm}$ arasında değişmesine rağmen bu olguların sadece bir kaçında müsinöz kistadenokarsinom rapor edilmiştir. Operasyonda; kistadenom ya da hiperplazide apendektomi yeterli tedavi olarak görülse de kistadenokarsinomda sağ hemikolektomi yapılmalıdır. Bu olgumuz patolojik tanısı mikst adenonöroendokrin karsinom (nöroendokrin karsinom/ adenokarsinom oranı 30/70) olması dolayısyla literatürde tek olgudur.

Anahtar Sözcükler: Görüntüleme tetkikleri; kistadenokarsinom; mukosel. 